\title{
Archaeoseismological potential of the Indian subcontinent
}

\author{
Miklós Kázmér ${ }^{1, *}$, Ashit Baran Roy ${ }^{2}$ and Siddharth Prizomwala ${ }^{3}$ \\ ${ }^{1}$ Department of Palaeontology, Eötvös University \& MTA-ELTE Geological, Geophysical and Space Science Research Group, Budapest, Hungary \\ ${ }^{2}$ Department of Geology, Mohanlal Sukhadia University, Udaipur 313 001, India \\ ${ }^{3}$ Institute of Seismological Research, Raisan, Gandhinagar 382 009, India
}

\begin{abstract}
Mountainous perimeter of the Indian subcontinent is seismically active, while the Peninsula is considered a stable region. Short instrumental records of earthquakes in India make it imperative to use historical and archaeological means to understand the past seismic activity. We review the status of achaeoseismology in India, Pakistan and Bangladesh. Data are provided on seismic activity affecting Delhi, Konark (Odisha) and Mahabalipuram (Tamil Nadu) during historical times. The study intends to highlight the vital need to employ achaeoseismology coupled with other geological information to better assess the past seismological records.
\end{abstract}

Keywords: Archaeoseismology, historical earthquakes, instrumental observations, masonry structures.

ARCHAEOSEISMOLOGY is an emerging field in the study of past earthquakes based on the analysis of damaged archaeological sites ${ }^{1}$. Combined with document-based historical seismology ${ }^{2}$, and geology-based paleoseismo$\log \mathrm{y}^{3}$, it provides essential information on past earthquakes which occurred beyond the century-long span of instrumental seismology ${ }^{4-6}$. Archaeoseismology can be vague about the specific earthquake responsible for the destruction of sites, but it can find evidence for events unrecorded in historical documents.

There was hardly any documentation of earthquakes in the Indian subcontinent before the arrival of the British about two and a half centuries ago ${ }^{7}$. While some historical data have been recorded as far back in time as 1636 , most are available only since the second half of the 19th century $^{8}$. These have been compiled in form of monographs on historical earthquakes first by Oldham $^{9}$ and later by Iyengar and Sharma ${ }^{10}$, and others.

Instrumental observations started in 1898 with the establishment of the first seismograph in Pune, Maharashtra, India ${ }^{11}$. However, serious use of seismographs in the Indian subcontinent was initiated only after the incidence of the Koyna Dam earthquake in 1967. After the Bhuj earthquake of 2001, various seismic networks were established in the entire region of the Indian subcontinent. Unfortunately, even a decade-long instrumental

\footnotetext{
*For correspondence. (e-mail: mkazmer@gmail.com)
}

record is not sufficient to understand the recurrence of damaging earthquakes.

\section{Archeoseismology: Indian scenario}

Three archaeologically dated earthquakes were described from Harappan site of Kalibangan, Rajasthan, in 1963-64, based mainly on vivid interpretation of field data ${ }^{12}$. Some important data came later from Dholavira in Kachchh, Western Gujarat, based on seismic interpretation of Harappan destruction sites ${ }^{13}$. Bisht ${ }^{14}$ found places showing traces of seismic episodes during the third millennium $\mathrm{BC}$, based on the identification of three collapse levels. One of these includes a southward-tilted wall. Roy et al. ${ }^{15}$ highlighted the analytical approach, emphasizing that geomorphologic character of a seismic landscape in the Rann of Kachchh, western Gujarat, is to be interpreted together with the study of structural damage of buildings within that landscape. Recently, Shirvalkar and Rawat ${ }^{16}$ have suggested that the main event of seismicity took place around $2200 \mathrm{BC}$, which collapsed and tilted walls of a Matura Harappan settlement (Kotada Bhadli, Kachchh). Kovach et $a l .{ }^{13}$ provided details of the archaeological sites at Banbhore, Brahmanabad (Mansurah), Kalibangan and Dholavira in the Kachchh area (Table 1, Figure 1).

Rajendran $^{17}$ reported evidence of earthquake-related destruction in the Ter region in Maharashtra. He was also demonstrated evidence of restoration in several ancient Hindu temples in that area. Based on the identification of extensive damage in the 9th century Punvareshwar temple in the Manjal area in Kachchh, Rajendran et al. ${ }^{18}$ suggested that the Bhuj earthquake was the highest intensity earthquake in the peninsula in the past 1200 years. Photographs of rotated masonry of the 12th century Katarmal temple near Almora and evidence of restoration of temples bearing contemporary inscriptions in the Garwhal region, Uttarakhand indicate the importance of archaeoseismological observations for the analysis of Himalayan seismicity ${ }^{19}$.

Bilham and Lodi ${ }^{20}$ found active faults through documentation of damaged sites; they assigned seismic parameters to these features. The region around Mansurah in Sindh, Pakistan, has been generally perceived as a lowintensity seismic hazard zone, because it has witnessed 
REVIEW ARTICLE

Table 1. Important archaeoseismological sites in the Indian subcontinent. For locations see Figure 1

\begin{tabular}{|c|c|c|c|}
\hline Site & Country, State & Longitude/latitude & Reference \\
\hline Mansurah & Pakistan, Sindh & $25.882^{\circ} \mathrm{N}, 68.777^{\circ} \mathrm{E}$ & 20 \\
\hline Brahmanabad & Pakistan & $31^{\circ} 26^{\prime} 46^{\prime \prime} \mathrm{N}, 74^{\circ} 31^{\prime} 34^{\prime \prime} \mathrm{E}$ & 13,54 \\
\hline Samawani & Pakistan & $\sim 25^{\circ} 40^{\prime} 20^{\prime \prime} \mathrm{N}, 68^{\circ} 29^{\prime} 15^{\prime \prime} \mathrm{E}$ & 54 \\
\hline Banbhore & Pakistan & $24^{\circ} 45^{\prime} 20^{\prime \prime} \mathrm{N}, 67^{\circ} 31^{\prime} 25^{\prime \prime} \mathrm{E}$ & 13 \\
\hline Kalibangan & India, Rajasthan & $29^{\circ} 28^{\prime} 23^{\prime \prime} \mathrm{N}, 74^{\circ} 07^{\prime} 45^{\prime \prime} \mathrm{E}$ & 13 \\
\hline Khabha, Jaisalmer & India, Rajasthan & $26^{\circ} 48^{\prime} 31^{\prime \prime} \mathrm{N}, 70^{\circ} 37^{\prime} 43^{\prime \prime} \mathrm{E}$ & 29 \\
\hline Pandrethan & India, Jammu \& Kashmir & $34.056^{\circ} \mathrm{N}, 74.860^{\circ} \mathrm{E}$ & 21 \\
\hline Payar & India, Jammu \& Kashmir & $33.861^{\circ} \mathrm{N}, 74.9402^{\circ} \mathrm{E}$ & 21 \\
\hline Naranag & India, Jammu \& Kashmir & $34.3534^{\circ} \mathrm{N}, 74.9771^{\circ} \mathrm{E}$ & 21 \\
\hline Pattan & India, Jammu \& Kashmir & $34.153^{\circ} \mathrm{N}, 74.563^{\circ} \mathrm{E}$ & 21,23 \\
\hline Sugandhesa & India, Jammu \& Kashmir & $34.1530^{\circ} \mathrm{N}, 74.5622^{\circ} \mathrm{E}$ & 21 \\
\hline Chamba & India, Himachal Pradesh & $32^{\circ} 32^{\prime} 44^{\prime \prime} \mathrm{N}, 76^{\circ} 07^{\prime} 33^{\prime \prime} \mathrm{E}$ & 25 \\
\hline Qutub Minar complex & India, Delhi & $28^{\circ} 31^{\prime} 26^{\prime \prime} \mathrm{N}, 77^{\circ} 11^{\prime} 10^{\prime \prime} \mathrm{E}$ & Present study \\
\hline Dholavira & India, Gujarat & $23^{\circ} 53^{\prime} 14^{\prime \prime} \mathrm{N}, 70^{\circ} 12^{\prime} 48^{\prime \prime} \mathrm{E}$ & 13,15 \\
\hline Diu & India, Diu & $20^{\circ} 42^{\prime} 19^{\prime \prime} \mathrm{N}, 70^{\circ} 58^{\prime} 45^{\prime \prime} \mathrm{E}$ & 55 \\
\hline Ter & India, Maharashtra & $18^{\circ} 19^{\prime} 19^{\prime \prime} \mathrm{N}, 76^{\circ} 08^{\prime} 32^{\prime \prime} \mathrm{E}$ & 17 \\
\hline Talakad & India, Karnataka & $12^{\circ} 11^{\prime} 03^{\prime \prime} \mathrm{N}, 77^{\circ} 01^{\prime} 25^{\prime \prime} \mathrm{E}$ & 30 \\
\hline Mahabalipuram & India, Tamil Nadu & $12^{\circ} 36^{\prime} 59^{\prime \prime} \mathrm{N}, 80^{\circ} 11^{\prime} 57^{\prime \prime} \mathrm{E}$ & Present study \\
\hline Konark & India, Odisha & $19^{\circ} 53^{\prime} 15^{\prime \prime} \mathrm{N}, 80^{\circ} 05^{\prime} 41^{\prime \prime} \mathrm{E}$ & Present study \\
\hline Mahasthan & Bangladesh & $24^{\circ} 57^{\prime} 34^{\prime \prime} \mathrm{N}, 89^{\circ} 20^{\prime} 45^{\prime \prime} \mathrm{E}$ & 28 \\
\hline
\end{tabular}

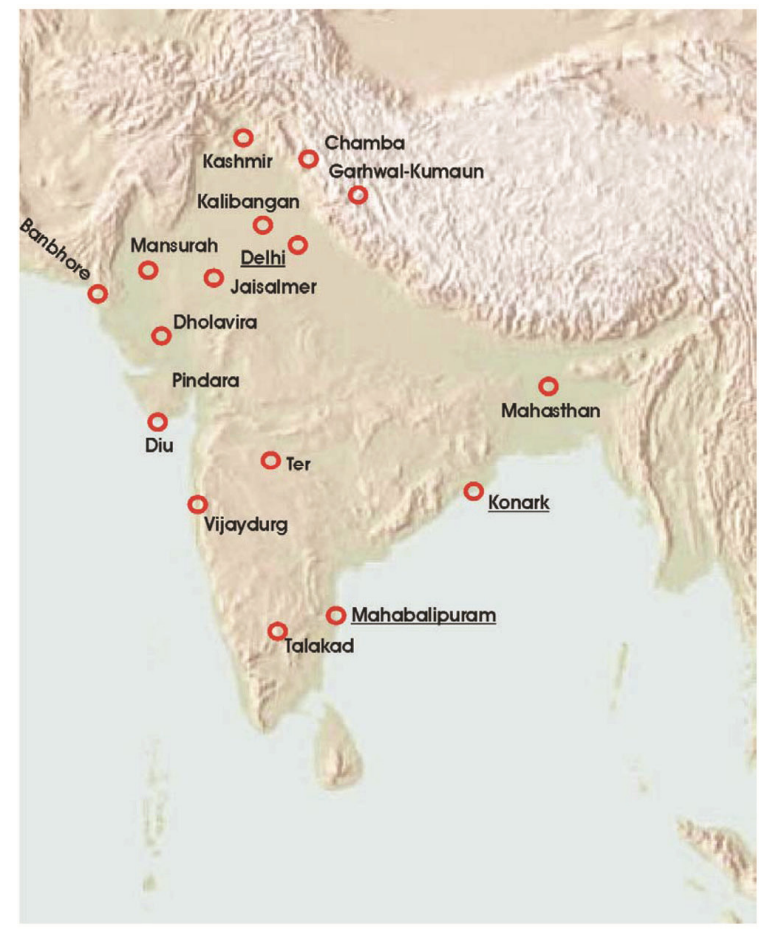

Figure 1. Sites of archaeoseismological studies in the Indian subcontinent (red circles). See Table 1 for details. Locations with new information presented in this study underlined.

only a few incidences of earthquakes in the past 200 years. They warn that this is dangerous thinking: there was an earthquake of intensity VIII only about 300 years ago $^{20}$. The authors suggested that the possibility of occurrence of a high-intensity earthquake cannot be ruled out in the future. A similar reasoning is advanced for the Pandrethan Hindu temple site in Kashmir, India, from archaeoseismic studies based on damaged masonry structures. Low-intensity instrumental data were countered by a high-intensity (VIII-IX) earthquake in the region ${ }^{21}$.

Masonry temples in Kashmir, which were affected by more than one earthquake, display structural damage. Assigning these to individual earthquakes is a difficult task. However, studies on earthquake-damaged temples in Garhwal and Kumaon, Uttarakhand ${ }^{22}$ allowed recognition of various earthquakes which had caused damage to these structures. Bilham et al. ${ }^{21}$ and Sana et al. ${ }^{23}$ used old photographs to separate blocks broken or fallen before and after the 1885 earthquake, when the images were taken. A similar approach was used by Malik et al $^{24}$ in Gujarat, based on a study of old drawings and sketches. Detailed deformation analysis of whole buildings and minor details of temples yielded information on directivity of seismic waves, allowing differentiation between two adjacent rupture zones active at different times ${ }^{25}$.

Damage of buildings is heavily influenced by the nature of the subsoil (hard rock or soft alluvium), and any preventive method against collapse applied by the builder. Hough et al. ${ }^{26}$ considered these factors when discussing repeated mega-earthquakes in Kashmir, based mostly on historical sources. Archaeological excavations can be supplemented by geophysical methods, including groundpenetrating radar. It is a useful tool to discover and describe displaced walls and warped floors at earthquakedamaged archaeological sites. This method helps understand the major earthquake which destroyed Ahichchhatra in Uttar Pradesh in the 11-12th century AD (refs 12, 27).

In low-lying, sediment-covered areas near the confluence of Ganga and Brahmaputra rivers, evidence of seismic destruction is dated by archaeological excavations. A good example comes from Mahasthangar in the Rajshahi 
division of Bangladesh through the study of the exhumed city wall, which collapsed during an earthquake in the 12th century AD (ref. 28).

Barring the study of Harappa sites and some other isolated places, archeoseismological studies in the Peninsula are limited in number. There are also examples of recent studies of earthquake-induced destruction of the Paliwal villages near Jaisalmer, Rajasthan ${ }^{29}$, and the Talakad temples near Mysore in Karnataka ${ }^{30}$.

Roy and Purohit ${ }^{31}$ advocated that there cannot be any better terrane than the Peninsular Indian Shield for initiating such studies in the future. The Peninsula has been persistently described as a 'stable continental region',32,33; though some potential, yet undetected seismic structures have been identified ${ }^{34}$. Youthful geomorphology and accentuated relief are in apparent contrast with low recorded seismicity. Studies on historical seismicity are slowly developing, while archaeoseismology of the Peninsula is still in its infancy. We wanted to add some data to its poorly understood seismic history, suggesting that archaeoseismology can contribute to the identification of seismically hazardous zones.

We conducted a preliminary study of three sites in order to highlight the importance of such studies in different parts of the Indian subcontinent. These include Qutub Minar complex in Delhi, Konark near Bhubaneswar (Odisha) and Mahabalipuram in the south of Chennai (Tamil Nadu). All these are considered to constitute parts of the 'stable' Indian Shield. A brief description of these studies seems appropriate to understand the importance of archaeoseismicity in the subcontinent outside the Himalayan terrain.

\section{Results}

\section{Studies around Delhi}

The Qutub Minar archaeological complex is a UNESCO World Heritage Site in the south of Delhi. Completed in AD 1198, it consists of the Quwwat-ul-Islam mosque, the screen to its sanctuary; the Qutub Minar, a $72 \mathrm{~m}$ high minaret; Alauddin's madrasa, the building for teaching; Alai Darwaza, the hall covering the southern gateway to the mosque, completed before 1311, and Alai Minar; a $24 \mathrm{~m}$ high portion of a minaret planned two times higher than Qutub Minar, but which remained unfinished in 1316. There are three tombs: Iltutmish's tomb from 1235 , Alauddin's tomb and Imam Zamin's tomb from 1538 (ref. 35). Whether Qutub Minar is a seismoscope for Himalayan earthquakes has been discussed by Rajendran et al. ${ }^{36}$.

Iltutmish's tomb, built by Shamsuddin Iltutmish (who ruled during 1211-1236) for himself in 1235, is a cubic building $13 \times 13 \mathrm{~m}$ in plan. It stands $9 \mathrm{~m}$ high in its present state (Figure 2). The walls are $2 \mathrm{~m}$ thick, made of light brown-coloured sandstone. There is evidence of major restoration: original richly carved portions alternate with later undecorated walls. At the top of the building we observed out-of-plane shift of masonry blocks producing about $5 \mathrm{~cm}$ wide gaps (Figure 3). Shifting of blocks is considered to have been caused by an earthquake of intensity IX on the EAE13 archaeoseismic scale $^{37}$. In 1803, an earthquake caused damage to the Qutub Minar proper ${ }^{22}$. However, a detailed study to record and interpret further features of damage is well worth the effort.

\section{Studies around Konark Temple, Odisha}

The Sun Temple at Konark (also Konarak) in Odisha is also a UNESCO World Heritage Site. The temple complex was built not long before AD 1264. The main temple

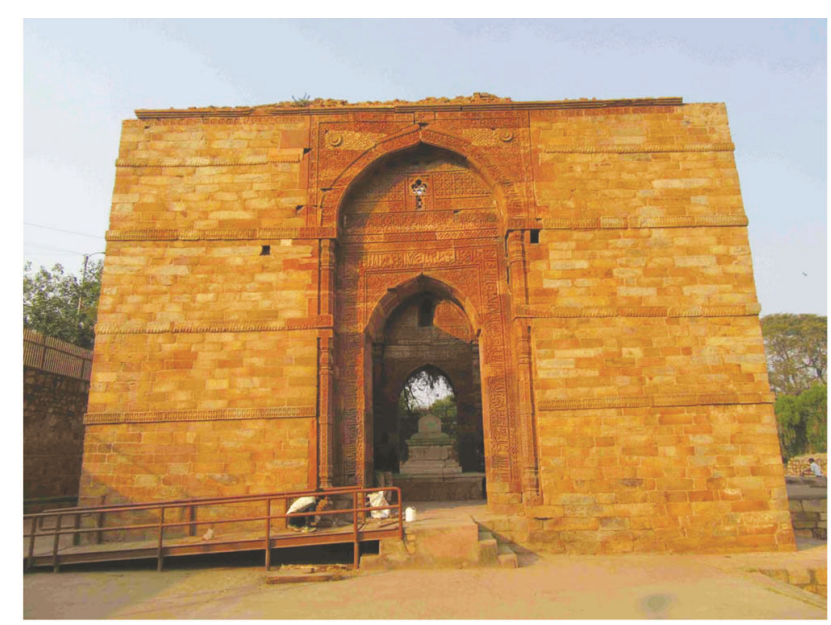

Figure 2. Thirteenth century tomb of Iltutmish, Qutub Minar complex, Delhi, India. White marble tombstone is visible through the southern gate. Photo \#1962.

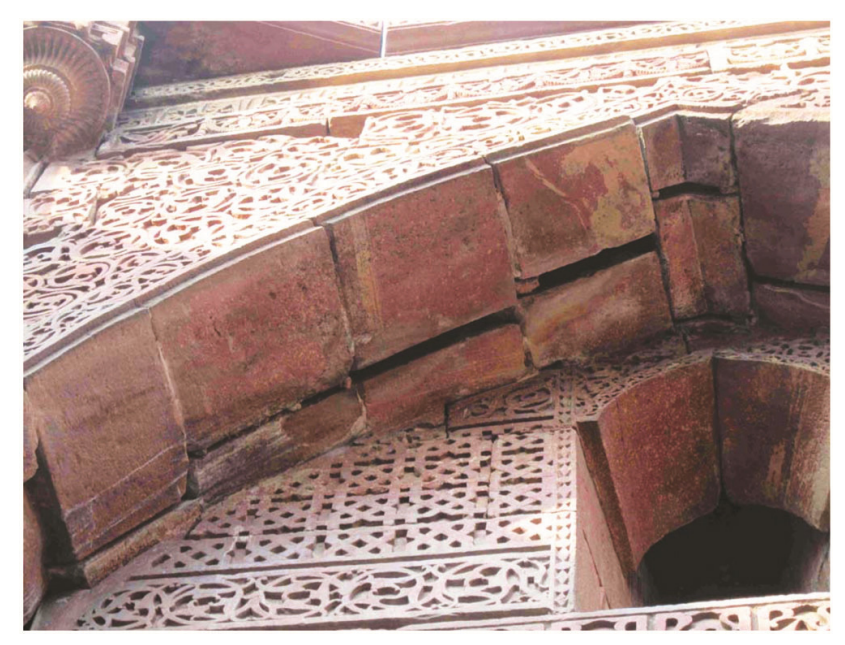

Figure 3. Inner facade of the northern gate in the Tomb of Iltutmish, Qutub Minar complex in Delhi. Out-of-plane shift of arch masonry blocks separated by more than $5 \mathrm{~cm}$ wide gap nearby the top of the entrance arch. Photo \#1941. 


\section{REVIEW ARTICLE}

consists of two parts: the existing jagamohana (forecourt) and the missing sikhara or deul (sanctuary), of which only the foundation has been preserved. The sikhara and deul collapsed some time after the 16th century, either due to problems in the foundation or because of an earthquake. There are some doubts if the temple was ever completed. However, there seems to be a consensus that the structure crumbled gradually ${ }^{38}$.

Smaller buildings surrounding the Sun Temple include the Mayadevi or Chhayadevi Temple (Temple 2) in the southwest. Intricately carved walls display shifted blocks. Both inplane and out-of-plane forces acted on the block, moving it diagonally outwards (Figure 4). An intensity IX was seen assigned to the earthquake responsible for this damage.

\section{Studies around Mahabalipuram}

Mahabalipuram town is situated $50 \mathrm{~km}$ south of Chennai. It is the proud site of a Hindu temple complex bearing UNESCO World Heritage tag. Two sites are notable: the Shore Temple in close proximity to the sea and the hilly area in the west, including erect monolithic temples carved from granite, cave-like underground temples, spectacular reliefs carved in granite hillside and natural rock formations.

The Shore Temple was built during the rule of King Narasimhavarman II, also known as Rajasimha (who ruled during AD 700-728). It consists of three shrines, two dedicated to Shiva and a smaller one between them, dedicated to Vishnu. The courtyard is partially surrounded by an unfinished enclosure (Figure 5). Outside the enclosure, west of the temple there is a bathing ghatlike structure, with stairs that lead down to a water body $^{39}$. Adjacent to the steps are the remnants of collapsed masonry wall and floor, tilted at various angles. One fragment of the former floor is now almost vertical

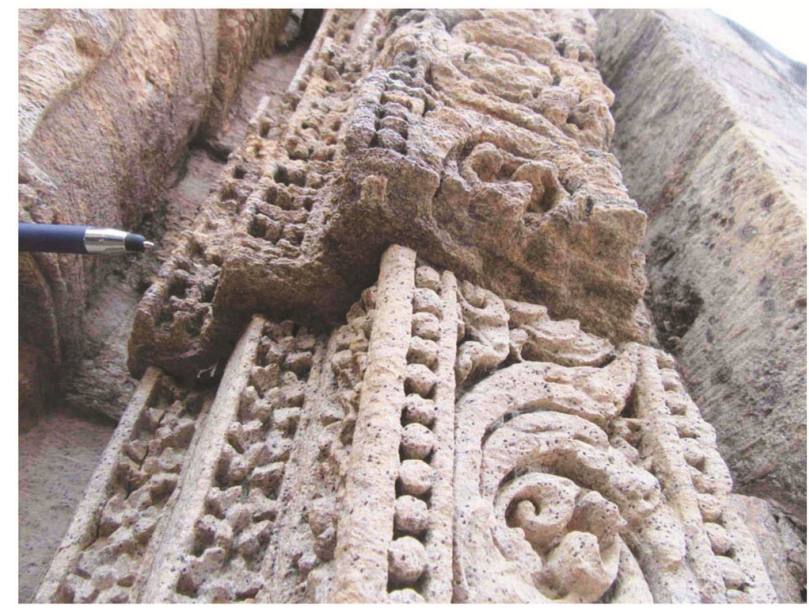

Figure 4. Shifted block in Mayadevi Temple at the Sun Temple complex, Konark, Odisha, India. Pen kept for scale. ADB Photo \#2751.
(Figure 6). The means of destruction is quite possibly liquefaction (fluidization) of the coastal sand on which the building was constructed, well after the Shore Temple was built. Liquefaction occurs when the contact between sand grains ceases due to a sudden increase in groundwater pore pressure, usually due to seismic shock. In this case the sediment behaves as fluid, and buildings construct on it are broken, tilted, or simply sink the sand ${ }^{40}$. An intensity IX has been assigned to this feature ${ }^{37}$.

\section{Why are these features evidence of an earthquake?}

At present not all of the frequent damages made by earthquakes on buildings are supported by analogue or digital modelling ${ }^{41,42}$. Exceptions are keystone drop ${ }^{43}$, not seen in India, and in-plane and out-of-plane shift of masonry blocks ${ }^{44}$. These features can be regarded as reliable indicators of severe seismic excitation.

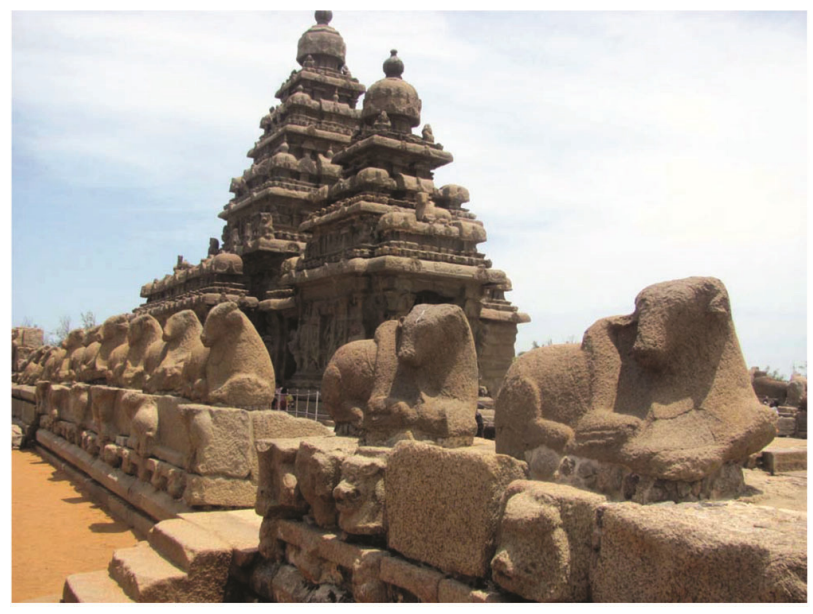

Figure 5. Shore Temple at Mahabalipuram, Tamil Nadu, India as seen from the northwest.

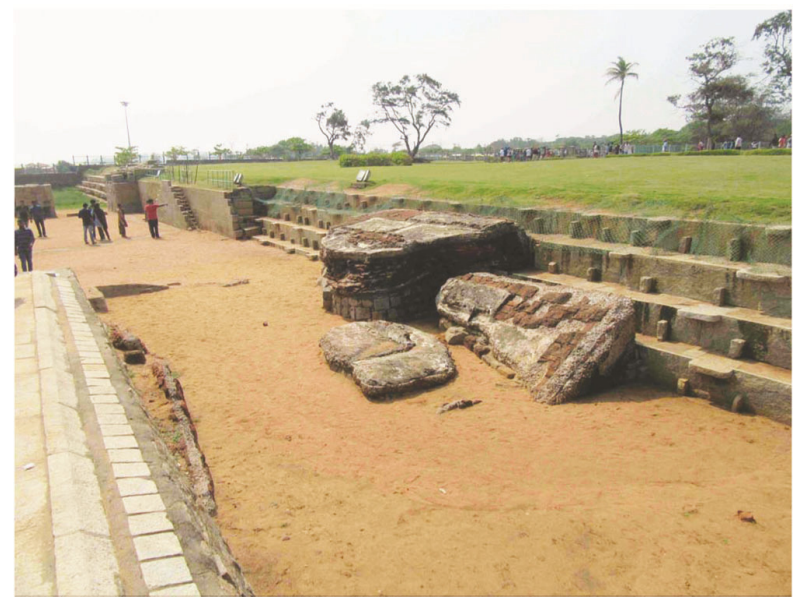

Figure 6. Collapsed walls and floor level of a brick building in the Shore Temple complex at Mahabalipuram. Tilted walls are evidence of liquefaction. Note vertically tilted wall on the left of the sandy floor. Persons in the background for scale. ADB Photo \#2166. 
Table 2. Archaeoseismological studies on the Indian subcontinent. The following civilizations are well known for their monumental constructions within the Indian subcontinent. Periods are after the Schwartzberg Atlas ${ }^{56}$ with additions, and after Torri. ${ }^{57}$. References to papers discussing earthquake damage to buildings from a given period are given in parentheses

\begin{tabular}{|c|c|c|}
\hline Period & Civilization & $\begin{array}{l}\text { Selected studies in } \\
\text { archaeoseismology }\end{array}$ \\
\hline $3300-1900 \mathrm{BC}$ & Harappan Civilization (Indus Valley Civilization) & Roy et al. ${ }^{15}$ \\
\hline $333-326$ вC & Alexander the Great brings Hellenistic influence to the west & Not yet studied \\
\hline $321-181 \mathrm{BC}$ & $\begin{array}{l}\text { Mauryan Empire: c. } 250 \text { BC Pillars of Ashoka: no Indian stone monuments before that time. } \\
\text { After the fall of the Maurya, Bactrian Greeks occupied the NW part of India. }\end{array}$ & Not yet studied \\
\hline $180 \mathrm{BC}-\mathrm{AD} 20$ & $\begin{array}{l}\text { Indo-Greek period. In total, the Greco-Buddhist artistic legacy lasted from the } 1 \text { st } \\
\text { century } \mathrm{BC} \text { until the } 4 \text { th century AD. }\end{array}$ & Not yet studied \\
\hline $200 \mathrm{BC}-\mathrm{AD} 300$ & Post-Mauryan period & Not yet studied \\
\hline AD 300-700 & $\begin{array}{l}\text { Classical age. At the end the Gupta Empire collapsed. The relatively minor but } \\
\text { artistically highly developed Pallava and Chola kingdoms flourished in the south. }\end{array}$ & Present study \\
\hline AD $700-1200$ & $\begin{array}{l}\text { Hindu architecture in parts. Gradual Islamic expansion (AD 700-1200), starting from the } \\
\text { northwest, had its influence in almost entire the subcontinent, but mostly missing in the south }\end{array}$ & $\begin{array}{l}\text { Bilham et al. }{ }^{21} \text {, Bilham and } \\
\text { Lodi }^{20} \text {, and Sana } \text { et } a l .{ }^{23}\end{array}$ \\
\hline $1170-1526$ & Delhi Sultanate (Islamic) & $\begin{array}{l}\text { Hough et al. }{ }^{26} ; \text { Present } \\
\text { study }\end{array}$ \\
\hline $1486-$ & $\begin{array}{l}\text { European expansion, starting with the Portuguese, Dutch, French, and finally completed by the } \\
\text { British }\end{array}$ & Kázmér et al..$^{55}$ \\
\hline
\end{tabular}

\section{Archaeoseismology: some geological considerations}

An important aspect which have dramatic impact on the Indian Shield in changing its character as a 'stable continental region' are the development of lineaments, many of which remained seismically active throughout human history. The lineaments which evolved earlier in geological history were reactivated later and acted as surfaces for transmitting the movement in the Indian subcontinent; the movements continue even today. The relative movement between the rigid blocks triggers seismicity, while the individual blocks remain mostly free from internal deformation.

\section{Importance of archaeoseismology in the Indian context}

Earthquake-damaged buildings provide strong and useful evidence of high-intensity seismic activity at a given site. The importance of archaeoseismic evidence is highlighted in some recent publications ${ }^{42,45,46}$.

Recognition of earthquake damage allows assessing intensity ${ }^{37}$. Date of the earthquake is to be constrained based on architectural history of the damaged structure. It is important to recognize repeated seismic events, as this provides the recurrence period of earthquakes at a given site. Sometime it is possible to assign a known dated historical event to the archaeoseismological event. It is preferred to study all possible sites in a given region, so that an intensity map can be drawn.

The Indian subcontinent is considered seismically stable when compared to the surrounding orogens ${ }^{47}$. However, this stability is apparent: while the Himalaya, for example, outlines the zone of high seismic hazard, the rest of the subcontinent possesses only scatter, indistinct seismic zones. The epicentres of all the known major present-day earthquakes on the Indian Shield are arranged either along the major lineaments or reasonably close to them $^{48}$. However, the data available are meagre. The earth movements that brought about major geomorphic changes must have also caused countless high-intensity earthquakes, most of which are without any studied records ${ }^{31}$. Lack of data is clearly shown on the seismic hazard map of Peninsular India ${ }^{48,49}$.

The occurrence of earthquakes at the interior of tectonic plates - assumed to be rigid in conventional plate tectonic theory-indicates that internal stress accumulates on faults and is released during large, but rare events ${ }^{50,51}$. Intraplate earthquakes - in India and elsewhere - often occur along failed rifts ${ }^{52}$, where anomalies of the local and regional stress field (for example at step over, en echelon faults) reach the level of uniform stress over the subcontinent. Successive earthquakes occur on different structures, yielding an absence of repeat earthquakes, at least on temporal scales of human observation ${ }^{53}$. Although the recurrence of earthquakes is possible along well-defined faults in intra-plate environments on thousands to tens of thousands of years if $a n y^{50}$, the awareness of their possibility is still worth to do studies on historical and archaeoseismology.

In the Indian context, seismically active regions with short instrumental and somewhat longer historical records can readily be studied by archaeoseismology. Seismically less active regions are also suitable for these studies, proving that low level does not mean lack of seismicity. Archaeoseismological projects will enrich earthquake catalogues by adding date (usually a date interval), location, intensity and strong motion directivity data. In the Indian subcontinent and its mountainous frame there are 


\section{REVIEW ARTICLE}

significant and well-researched studies available, as outlined above. The concept of 'stable' interior of the Peninsula has been proved to be a myth. Information through published data is available. The present study emphasizes the possibility of successful archaeoseismological research in view of the presence of important archaeological sites of different ages in the Indian subcontinent.

All historical periods of the subcontinent have witnessed masonry buildings, which are worth studying (Table 2). The most widespread are those from the construction period of the 7 th to 12 th century AD. At those times there were strong, centralized states investing in memorial masonry buildings. Availability of suitable raw material and capable workforce created monuments for eternity. Any damage or demolition of these buildings must be considered - beyond the common causes of manmade damage, neglect or weather calamity - as caused by earthquakes. Properly carved masonry is the best to recognize minor displacements causing misfit of stones. However, the Indian way of stone-carving, with attention to minute details makes it hard - but not impossible - to recognize these displacements.

Intensive restoration by various rulers throughout the millennia, followed by the attention of British colonial authorities and by the Archaeological Survey of India in modern times modified and re-built collapsed parts and used other methods to hide or replace damaged portions, e.g. shifted blocks. While restoration ensures that ancient buildings will exist in future, it commonly destroys evidence of past seismicity. This is not an Indian problem alone: ideally a trained archaeoseismologist should survey all buildings before large-scale restoration projects are begun.

1. Stiros, S. C. and Jones, R. E. (eds), Archaeoseismology, British School at Athens, Fitch Laboratory Occasional Paper, 1997, vol. 7, p. 268

2. Guidoboni, E. and Ebel, J., Earthquakes and Tsunamis in the Past. A Guide to Techniques in Historical Seismology, Cambridge University Press, Cambridge, UK, 2009.

3. McCalpin, J., Paleoseismology, Academic Press, San Diego, USA, 1999.

4. Dewey, J. and Byerly, P., The early history of seismometry (to 1900). Bull. Seismol. Soc. Am., 1969, 59(1), 183-227.

5. Rodríguez-Pascua, M. A., Silva, P. G., Giner-Robles, J. L., PérezLópez, R., Perucha, M. and Martín-González, F., Arquesismología: una nueva herramenienta para la sismología y la protección del patrimonio. Rev. Otarq, 2016, 1, 151-169.

6. Silva, P. G., Reicherter, K., Giner-Robles, J. L., RodríguezPascua, M. A., Grützner, Ch., García-Jiménez, P. and PérezLópez, R., Arqueosismología del Conjunto Arqueológico Romano de Baelo Claudia (Cádiz, Sur de España): estado de la cuestión. II Jornadas Internacionales de Baelo Claudia, 2016, pp. 63-91.

7. Roy, A. B., Seismicity in the Peninsular Indian Shield: some geological considerations. Curr. Sci., 2006, 91(4), 456-463.

8. Martin, S. and Szeliga, W., A catalog of felt intensity data for 570 earthquakes in India from 1639 to 2009. Bull. Seismol. Soc. Am. 2010, 100(2), 562-569.

9. Oldham, T., A catalogue of Indian earthquakes. Mem. Geol. Surv. India, 1883, 19, 163-2015.
10. Iyengar, R. N. and Sharma, S. D., Earthquake History of India in Medieval Times, Central Building Research Institute, Roorkee, 1999.

11. Jain, S. K. and Nigam, N. C., Historical developments and current status of earthquake engineering in India. In 12th World Conference on Earthquake Engineering, Auckland, New Zealand, 30 January-4 February 2000, Paper no. 1792, p. 8.

12. Vikrama, B. H., Sravanthi, S., Malik, J. N. and Dikshit, O., Archaeological evidences for a 12th-14th century earthquake at Ahichhatra, Barreilly (UP), India. In International Symposium on the 2001 Bhuj Earthquake and Advances in Earthquake Science AES-2001, Institute of Seismological Research, Gandhinagar, 22-24 January 2011, pp. 113-114.

13. Kovach, R. L., Grijalva, K. and Nur, A., Earthquakes and civilizations of the Indus Valley: a challenge for archaeoseismology. Geol. Soc. Am. Spec. Pap., 2010, 471, 119-127.

14. Bisht, R. S., Major earthquake occurrences in archaeological strata of Harappan settlement at Dholavira (Kachchh, Gujarat). In International Symposium on the 2001 Bhuj Earthquake and Advances in Earthquake Science-AES-2001, Institute of Seismological Research, Gandhinagar, 22-24 January 2011, pp. 112-113.

15. Roy, A. B., Chatterjee, A. and Chauhan, N. K., Late Quaternary deformation and paleoseismicity: insight into geomorphotectonic evolution of Kachchh, western Indian subcontinent. J. Geol. Soc. India, 2013, 81, 31-40.

16. Shirvalkar, P. and Rawat, Y. S., Excavations at Kotada Bhadli. In Taluka: Nakhatrana, District: Kachchh Gujarat, 2010-2014. Wheeler Excavation Report, Archaeological Survey of India, New Delhi, May 2017, p. 208.

17. Rajendran, C. P., Deformational features in the river bluffs at Ter, Osmanabad district, Maharashtra: evidence for an ancient earthquake. Curr. Sci., 1997, 72(10), 750-755.

18. Rajendran, K., Rajendran, C. P., Thakkar, M. and Tuttle, M. P., The 2001 Kutch (Bhuj) earthquake: coseismic surface features and their significance. Curr. Sci., 2001, 80(11), 1397-1405.

19. Rajendran, C. P. and Rajendran, K., The status of the central seismic gap: a perspective based on the spatial and temporal aspects of the large Himalayan earthquakes. Tectonophysics, 2005, 395, 19-39.

20. Bilham, R. and Lodi, S., The door knockers of Mansurah: strong shaking in a region of low perceived seismic risk, Sindh, Pakistan. Geol. Soc. Am. Spec. Pap, 2010, 471, 29-37.

21. Bilham, R., Bali, B. R., Bhat, M. I. and Hough, S., Historical earthquakes in Srinagar, Kashmir: clues from the Shiva temple at Pandrethan. Geol. Soc. Am. Spec. Pap., 2010, 471, 1-12.

22. Rajendran, C. P., Rajendran, K., Sanwal, J. and Sandiford, M., Archeological and historical database on the Medieval earthquakes of the Central Himalaya: ambiguities and inferences. Seismol. Res. Lett., 2013, 84(6), 1098-1108.

23. Sana, H., Bhat, F. A. and Sana, S., The ancient temples of Kashmir turned from marvel to ruin by earthquakes? A case study of the Pattan twin temples (AD 883-902). Seismol. Res. Lett., 2018, 90(1), 358-365.

24. Malik, J. N., Gadhavi, M. S., Satuluri, S., Kumar, S., Sahoo, S. and Vikrama, B., Unravelling the hidden truth from Vigukot in the Great Rann of Kachchh, western India by surface and sub-surface mapping. Curr. Sci., 2017, 113(10), 1906-1917.

25. Joshi, M. and Thakur, V. C., Signatures of 1905 Kangra and 1555 Kashmir earthquakes in Medieval period temples of Chamba Region, northwest Himalaya. Seismol. Res. Lett., 2016, 87, 11501160 .

26. Hough, S., Bilham, R. and Bhat, I., Kashmir Valley megaerthquakes. Am. Sci., 2009, 97, 42-49.

27. Sravanthi, S., Malik, J. N. and Vikrama, B., Ground penetrating radar investigations at Ahichchhatra: an attempt to identify buried subsurface structures. In 14th International Conference on Ground Penetrating Radar, Shanghai, China, 4-8 June 2012, pp. 625-630. 
28. Helly, B., Berliet, E. and Faticoni, B., Archaeology of earthquakes at Mahasthangar (Province of Bogra, Bangladesh). In International Symposium on the 2001 Bhuj Earthquake and Advances in Earthquake Science - AES-2001, Institute of Seismological Research, Raisan, Gandhinagar, Gujarat, 22-24 January 2011, pp. 116117.

29. Roy, A. B., Bhu, H., Sharma, P. and Vaishnav, K., Deserted nineteenth century Paliwal villages around Jaisalmer, western Rajasthan, India: historical evidence of palaeoseismicity. Curr. Sci., 2017, 112(5), 402-405.

30. Roy, A. B. and Sethumadhav, M. S., The 'mystic' sand-dune covered temples of Talakad, Mysore district, Karnataka: evidence of earthquake-related destruction. Curr. Sci., 2014, 107(2), 246-254.

31. Roy, A. B. and Purohit, R., Indian Shield. Precambrian Evolution and Phanerozoic Reconstitution. Elsevier, Amsterdam, The Netherlands, 2018, p. 356.

32. Rastogi, B. K. et al., The deadliest stable continental region earthquake occurred near Bhuj on 26 January 2001. J. Seismol., 2001, 5, 609-615.

33. Nath, S. K. and Thingbaijam, K. K. S., Probabilistic seismic hazard assessment of India. Seismol. Res. Lett., 2012, 83(1), 135-149.

34. Rajendran, C. P., Whose fault is it? Curr. Sci., 2011, 101(3), 263264.

35. Page, J. A. and Sharma, Y. D., Qutb Minar and Adjoining Monuments, World Heritage Series, Archaeological Survey of India, New Delhi, 2002.

36. Rajendran, C. P. et al., Footprints of an elusive mid-14th century earthquake in the central Himalaya: Consilience of evidence from Nepal and India. Geol. J., 2019, 54, 2829-2846.

37. Rodríguez-Pascua, M. A., Silva, P. G., Peérez-López, R., GinerRobles, J.-L., Martín-González, F. and Perucha, M. A., Preliminary intensity correlation between macroseismic scales (ESI07 and EMS98) and earthquake archaeological effects (EAEs). In Seismic Hazard, Critical facilities and Slow Active Faults. PATA Days (eds Grützner, C. et al.), Proceedings of the 4th International INQUA Meeting on Paleoseismology, Active Tectonics and Archaeoseismology (PATA), Aachen, Germany, 9-14 October 2013, pp. 221-224.

38. Mitra, D., Konarak, World Heritage Series, Archaeological Survey of India, New Delhi, 2003.

39. Sivaramamurti, C. and Narasimhaiah, B., Mahabalipuram, World Heritage Series, Archaeological Survey of India, New Delhi, 2006.

40. Bray, J. D. and Dashti, S., Liquefaction-induced building movements. Bull. Earthq. Eng., 2014, 12, 1129-1156.

41. Rodríguez-Pascua, M. A., Pérez-López, R., Giner-Robles, J. L. and Garduño-Monroy, V. H., A comprehensive classification of earthquake archaeological effects (EAE) in archaeoseismology: application to ancient remains of Roman and Mesoamerican cultures. Quaternary Int., 2011, 242, 20-30.

42. Kázmér, M., Damage to ancient buildings from earthquakes. In Encyclopedia of Earthquake Engineering (eds Beer, M. et al.), Springer, Berlin, Germany, 2015, pp. 500-506.

43. Kamai, R. and Hatzor, Y. H., Numerical analysis of block stone displacements in ancient masonry structures: a new method to estimate historic ground motions. Int. J. Num. Anal. Methods Geomech., 2008, 32, 1321-1340.

44. Vasconcelos, Lourenço, P. B., Mouzakis, H. and Karapitta, L., Experimental investigations on dry stone masonry walls. In $1 \mathrm{st}$ International Conference on Restoration of Heritage Masonry Structures, Cairo, Egypt, 24-27 April 2006, pp. P31-1-P31-10.

45. Marco, S., Recognition of earthquake-related damage in archaeological sites: examples from the Dead Sea fault zone. Tectonophysics, 2008, 453, 148-156.

46. Silva, P. G., Sintubin, M. and Reicherter, K., New advances in studies of earthquake archeology and paleoseismology. Quaternary Int., 2011, 242(1), 1-3.

47. Kayal, J. R., Seismotectonics of Peninsular India and Sri Lanka. In Microearthquake Seismology and Seismotectonics of South Asia, Springer, Dordrecht, The Netherlands, 2008, pp. 348-449.

48. Murthy, Y. S. and Raval, U., Bouguer gravity image of India and the neighbouring ESCAP region: a study of tectonics and natural resources. J. Geophys., 2000, 21, 59-70.

49. Ashish, Lindholm, C., Parvez, I. A. and Kühn, D., Probabilistic earthquake hazard assessment for Peninsular India. J. Seismol., 2016, 20, 629-653.

50. Calais, E., Mattioli, G., DeMets, C., Nocquet, J.-M., Stein, S., Newman, A. and Rydelek, P., Tectonic strain in plate interiors? Nature, 2005, 438, E9-E10.

51. Craig, T. J., Calais, E., Fleitout, L., Bollinger, L. and Scotti, O., Evidence for the release of long-term tectonic strain stored in continental interiors through intraplate earthquakes. Geophys. Res. Lett., 2016, 43, 6826-6836.

52. Gangopadhyay, A. and Talwani, P., Symptomatic features of intraplate earthquakes. Seismol. Res. Lett., 2003, 74(6), 863-883.

53. Talwani, P., On the nature of intraplate earthquakes. J. Seismol., 2017, 21, 47-68.

54. Bilham, R., Lodi, S., Hough, S., Bukhary, S., Khan, A. M. and Rafeeqi, S. F. A., Seismic hazard in Karachi, Pakistan: uncertain past, uncertain future. Seismol. Res. Lett., 2007, 78(6), 601-613.

55. Kázmér, M., Bhatt, N., Ukey, V., Prizomwala, S., Taboroši, D. and Székely, B., Archaeological evidence for modern coastal uplift at Diu, Saurashtra Peninsula, India. Geoarchaeology, 2016, 31(5), 376-387.

56. Schwartzberg, J. (ed.), A Historical Atlas of South Asia, Chicago University Press, Chicago, USA, 1978; http://dsal.uchicago.edu/ reference/schwartzberg/ (accessed on 8 January 2019).

57. Torri, M., For a new periodization of Indian history: the history of India as part of the history of the world. Stud. Hist., 2014, 30(1), 89-108.

ACKNOWLEDGEMENTS. We thank Kaushik Dey for assistance during field work and the anonymous reviewer for providing insightful and constructive comments that helped to improve the manuscript. S.P. thanks the Department of Geology, Institute of Seismological Research, Gandhinagar for support.

Received 24 June 2019; revised accepted 24 September 2020

doi: $10.18520 / \mathrm{cs} / \mathrm{v} 119 / \mathrm{i} 11 / 1767-1773$ 